\title{
Wind Turbine Safety and Function Test Report for the ARE 442 Wind Turbine
}

Technical Report NREL/TP-500-47030

February 2010

J. van Dam, D. Baker, and D. Jager 


\section{Wind Turbine Safety and Function Test Report for the ARE 442 Wind Turbine}

\section{Technical Report}

NREL/TP-xxx-xxxxx

Month Year (Arial 12 pt Bold)

J. van Dam, D. Baker, and D. Jager

Prepared under Task No. WE10.2211

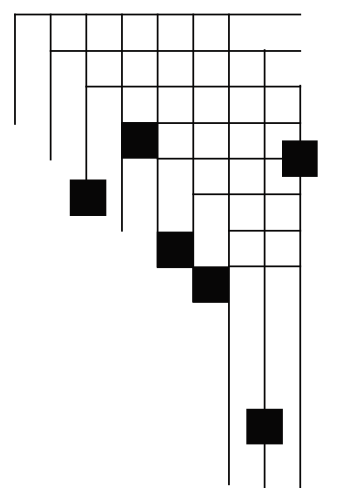

National Renewable Energy Laboratory

1617 Cole Boulevard, Golden, Colorado 80401-3393

303-275-3000 • www.nrel.gov

NREL is a national laboratory of the U.S. Department of Energy

Office of Energy Efficiency and Renewable Energy

Operated by the Alliance for Sustainable Energy, LLC

Contract No. DE-AC36-08-GO28308 


\section{NOTICE}

This report was prepared as an account of work sponsored by an agency of the United States government. Neither the United States government nor any agency thereof, nor any of their employees, makes any warranty, express or implied, or assumes any legal liability or responsibility for the accuracy, completeness, or usefulness of any information, apparatus, product, or process disclosed, or represents that its use would not infringe privately owned rights. Reference herein to any specific commercial product, process, or service by trade name, trademark, manufacturer, or otherwise does not necessarily constitute or imply its endorsement, recommendation, or favoring by the United States government or any agency thereof. The views and opinions of authors expressed herein do not necessarily state or reflect those of the United States government or any agency thereof.

Available electronically at http://www.osti.gov/bridge

Available for a processing fee to U.S. Department of Energy and its contractors, in paper, from:

U.S. Department of Energy

Office of Scientific and Technical Information

P.O. Box 62

Oak Ridge, TN 37831-0062

phone: 865.576 .8401

fax: 865.576 .5728

email: mailto:reports@adonis.osti.gov

Available for sale to the public, in paper, from:

U.S. Department of Commerce

National Technical Information Service

5285 Port Royal Road

Springfield, VA 22161

phone: 800.553.6847

fax: 703.605.6900

email: orders@ntis.fedworld.gov

online ordering: http://www.ntis.gov/ordering.htm 


\section{Notice}

This report was prepared by the National Renewable Energy Laboratory (NREL), operated for the United States Department of Energy (DOE) by the Alliance for Sustainable Energy, LLC (Alliance), as an account of work sponsored by the United States government. The test results documented in this report define the characteristics of the test article as configured and under the conditions tested.

THIS REPORT IS PROVIDED "AS IS" AND NEITHER THE GOVERNMENT, ALLIANCE, NREL NOR ANY OF THEIR EMPLOYEES, MAKES ANY WARRANTY, EXPRESS OR IMPLIED, INCLUDING THE WARRANTIES OF MERCHANTABILITY AND FITNESS FOR A PARTICULAR PURPOSE, OR ASSUMES ANY LEGAL LIABILITY OR RESPONSIBILITY FOR THE ACCURACY, COMPLETENESS, OR USEFULNESS OF ANY SUCH INFORMATION DISCLOSED IN THE REPORT, OR OF ANY APPARATUS, PRODUCT, OR PROCESS DISCLOSED, OR REPRESENTS THAT ITS USE WOULD NOT INFRINGE PRIVATELY OWNED RIGHTS.

Neither Alliance nor the U. S. Government shall be liable for special, consequential or incidental damages. Reference herein to any specific commercial product, process, or service by trade name, trademark, manufacturer, or otherwise does not necessarily constitute or imply its endorsement, recommendation, or favoring by the United States government or any agency thereof. The views and opinions of the authors expressed herein do not necessarily state or reflect those of the United States government or any agency thereof or Alliance.

NREL is a DOE Laboratory, and as an adjunct of the United States government, cannot certify wind turbines. The information in this report is limited to NREL's knowledge and understanding as of this date.

NREL is accredited by the American Association for Laboratory Accreditation (A2LA) and the results shown in this test report have been determined in accordance with the NREL's terms of accreditation unless stated otherwise in the report.

This report shall not be reproduced, except in full, without the written approval of Alliance or successor operator of NREL.

Approval By:

Jeroen van Dam, NREL Test Engineer

Date

Approval By:

Amy Bowen, NREL Test Engineer

Date 


\section{Table of Contents}

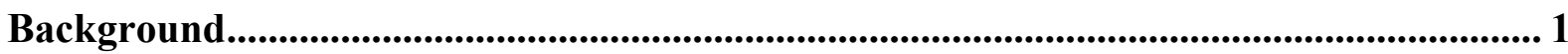

Test Objective ...................................................................................................................................... 1

Description of Test Turbine and Setup ...................................................................................... 1

Instrumentation.............................................................................................................................. 5

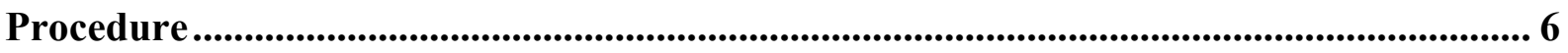

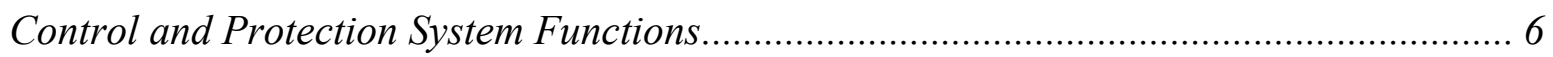

Personnel Safety Provisions ...................................................................................................... 7

Dynamic Behavior ................................................................................................................... 7

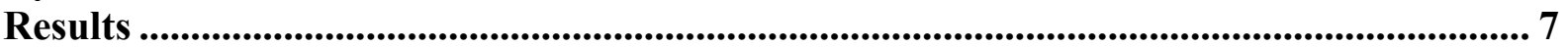

Control and Protection System Functions.................................................................... 7

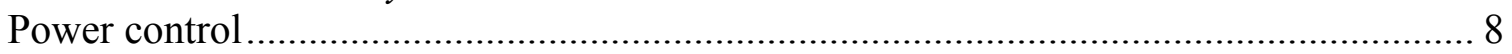

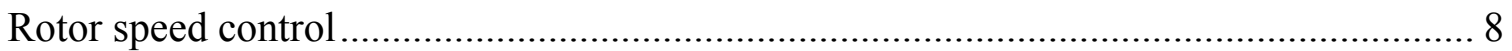

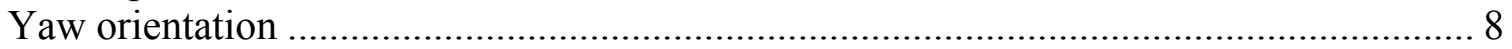

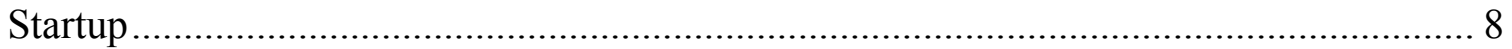

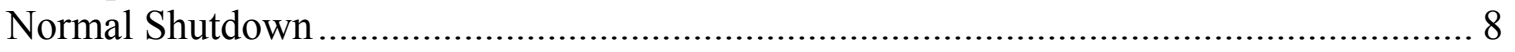

Emergency shutdown during operation from any operating condition ............................. 8

Behavior upon excessive vibration .............................................................................. 9

Behavior upon loss of load ..................................................................................... 9

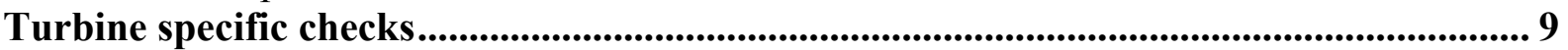

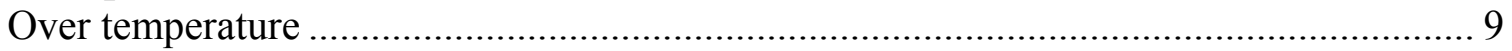

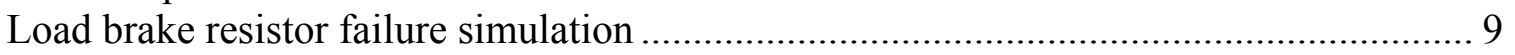

Personnel Safety Provisions ............................................................................................................. 10

Safety Instructions ………………………… 10

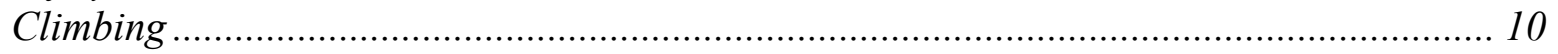

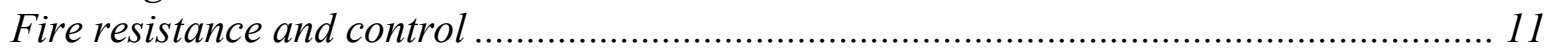

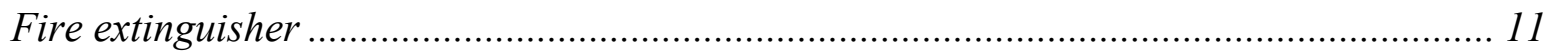

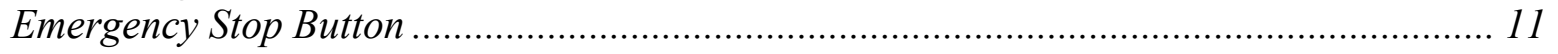

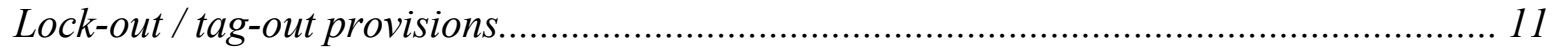

Interlock on electrical cabinets ................................................................................ 11

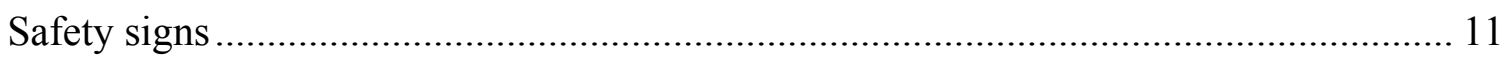

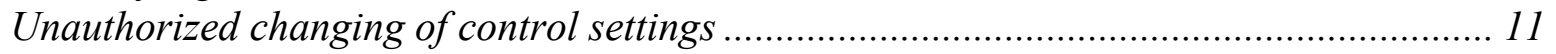

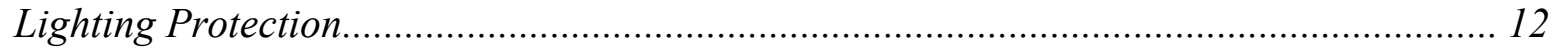

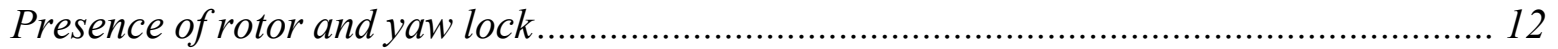

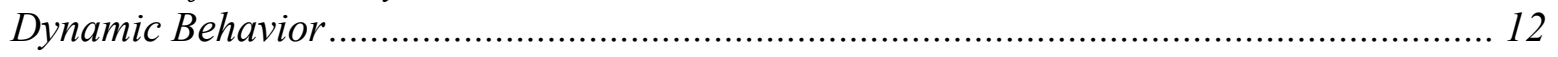

Deviations and Exceptions............................................................................................................... 20

Deviations from the Standard................................................................................... 20

Exceptions to the NWTC Quality Assurance System ....................................................... 20

Appendix A - Instrument Calibration Sheets ......................................................................... 21 


\section{List of Figures}

Figure 1. ARE 442 wind turbine at the NWTC test site .................................................. 3

Figure 2. Electrical Drawing of the ARE 442 installation ................................................... 4

Figure 3. Power response to wind speed (red- maxima, green - minima, blue -average)........ 12

Figure 4. Rotor speed response to wind speed (red- maxima, green - minima, blue -average) 13

Figure 5. Time series of a high rpm event (datafile ARE081230_001156)............................ 14

Figure 6. Turbine response during a simulated grid outage -- the IGBT's failed. (datafile

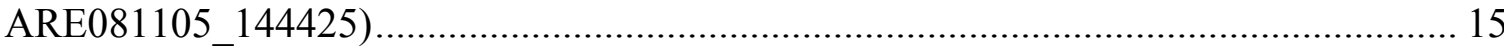

Figure 7. Simulated grid outage in low winds (data file ARE090720_115146)................... 16

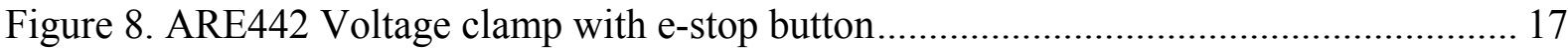

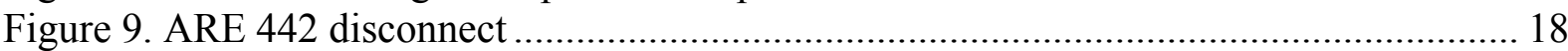

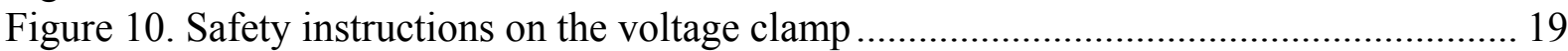

Figure 11. Safety instruction tag on the TUF TUG climbing system ............................... 20

Figure A.1. Power transducer calibration sheet ................................................................ 21

Figure A.2. Primary anemometer calibration sheet ................................................... 22

Figure A.4. NI 9229 data acquisition module calibration sheet I ....................................... 23

Figure A.5. NI 9217 data acquisition module calibration sheet I ...................................... 24

Figure A.6. NI 9205 data acquisition module calibration sheet I .................................... 25

Figure A.7. NI 9229 data acquisition module calibration sheet II ...................................... 26

Figure A.8. NI 9217 data acquisition module calibration sheet II ....................................... 27

Figure A.9. NI 9205 data acquisition module calibration sheet II .................................... 28

\section{List of Tables}

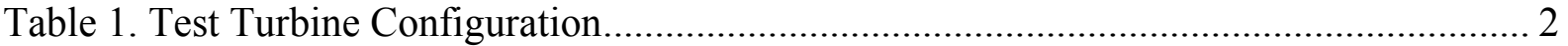

Table 2. Equipment List for Safety and Function Test ..................................................... 5 


\section{Background}

This test was conducted as part of the U.S. Department of Energy's (DOE) Independent Testing project. This project was established to help reduce the barriers of wind energy expansion by providing independent testing results for small turbines. In total, four turbines were tested at the National Wind Technology Center (NWTC) as a part of this project. Safety and function testing is one of up to five tests that were performed on the turbines, including power performance, duration, noise, and power quality tests. Test results provide manufacturers with reports that can be used for small wind turbine certification.

The test equipment includes an ARE 442 wind turbine mounted on a 100-ft free-standing lattice tower. The system was installed by the NWTC Site Operations group with guidance and assistance from Abundant Renewable Energy.

\section{Test Objective}

The objective of this test is to:

- verify that the test turbine displays the behavior predicted in the design

- determine if provisions relating to personnel safety are properly implemented

- characterize the dynamic behavior of the wind turbine at rated wind speed and above.

NREL does not limit the safety and function test to features described in the wind turbine documentation. NREL also inspects, possibly tests, and reports on features that are required by IEC $61400-2$ that may not be described in the wind turbine documentation.

NREL conducted this test in accordance with Section 9.6 of the International Electrotechnical Commission (IEC) standard, Wind Turbines - Part 2: Design requirements for small wind turbines, IEC 61400-2, Second edition, 2006-03.

\section{Description of Test Turbine and Setup}

The test turbine was an ARE 442 wind turbine. This turbine is an upwind three-bladed side furling turbine with a rated power of $10 \mathrm{~kW}$. Table 1 provides the key descriptive information of the test turbine.

The ARE 442 wind turbine was installed at site 3.3a at the National Wind Technology Center located eight miles south of Boulder, Colorado (Figure 1). The location primarily consists of mostly flat terrain with short vegetation. The test site has prevailing wind, bearing 292 degrees, relative to true north $\left(292^{\circ} \mathrm{T}\right)$. For measurements where it is important to accurately measure wind speed, NREL used data obtained when wind direction is between $214^{\circ} \mathrm{T}$ and $72^{\circ} \mathrm{T}$. In this measurement sector, which was established in accordance with IEC 61400-12-1, the influence of terrain and obstructions on the anemometer and turbine is small.

A one line diagram of the turbine system is provided in Figure 2. 
Table 1. Test Turbine Configuration

\begin{tabular}{|l|l|}
\hline Turbine manufacturer and address & $\begin{array}{l}\text { Abundant Renewable Energy } \\
\text { 22700 NE Mountain Top Road } \\
\text { Newberg OR 97132 }\end{array}$ \\
\hline Model name & ARE 442 \\
\hline Serial number & Y08-001C \\
\hline Production date & January 2008 \\
\hline $\begin{array}{l}\text { Design nominal voltage at terminals } \\
\text { (VAC) }\end{array}$ & 240 \\
\hline Maximum current at terminals (A) & 55 \\
\hline Design frequency at terminals (Hz) & 60 \\
\hline SWT class & II \\
\hline $\begin{array}{l}\text { Design 50-year extreme wind speed, } \\
\text { Ve50 (m/s) }\end{array}$ & 59.5 \\
\hline Rotor Diameter (m) & 7.2 \\
\hline $\begin{array}{l}\text { Hub Height (vertical center of rotor) } \\
\text { (m) }\end{array}$ & 30.9 \\
\hline Tower Type & Freestanding Lattice Valmont U4.5 x 100' \\
\hline Rated Electrical Power (kW) & 10 \\
\hline $\begin{array}{l}\text { Rated Wind Speed (m/s) (lowest } \\
\text { wind speed at which turbine } \\
\text { produces rated power) }\end{array}$ & 11 \\
\hline $\begin{array}{l}\text { Rated rotor speed (rpm) (lowest } \\
\text { rotor speed at which turbine } \\
\text { produces rated power) }\end{array}$ & 140 \\
\hline Rotor speed range (rpm) & $0-160$ \\
\hline Fixed or variable pitch & Fixed \\
\hline Number of Blades & 3 \\
\hline Blade Tip Pitch Angle (deg) & 0, blade root flat on alternator \\
\hline Blade make, type, serial number & Aero Energy 089-028, 089-029, 089-030 \\
\hline $\begin{array}{l}\text { Description of control system } \\
\text { (device \& software version) }\end{array}$ & $\begin{array}{l}\text { Combination of side furling with gravity return, } \\
\text { VCL 442-HV voltage clamp and Windyboy } \\
\text { US6000 inverter software. }\end{array}$ \\
\hline
\end{tabular}




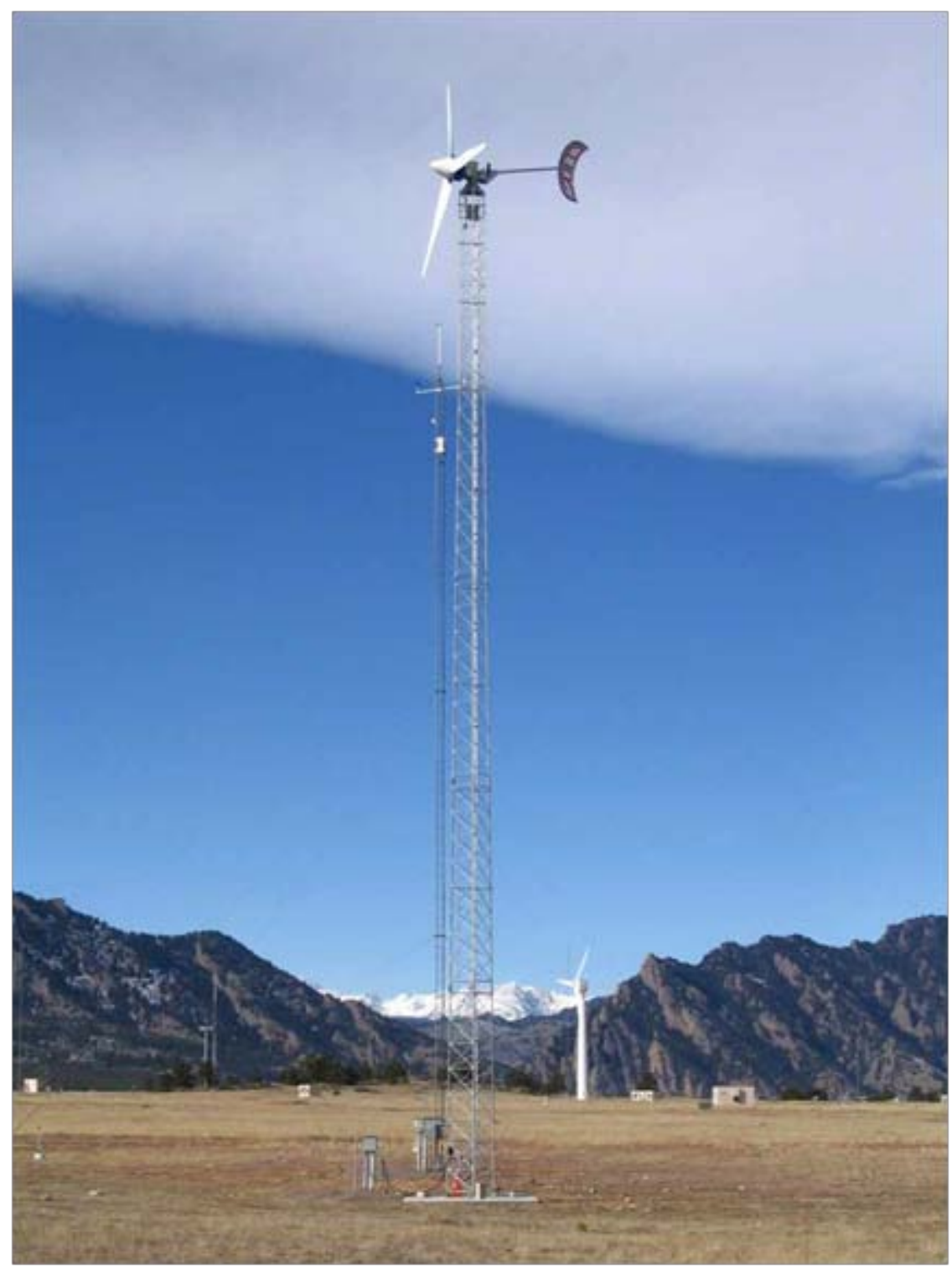

Figure 1. ARE 442 wind turbine at the NWTC test site 


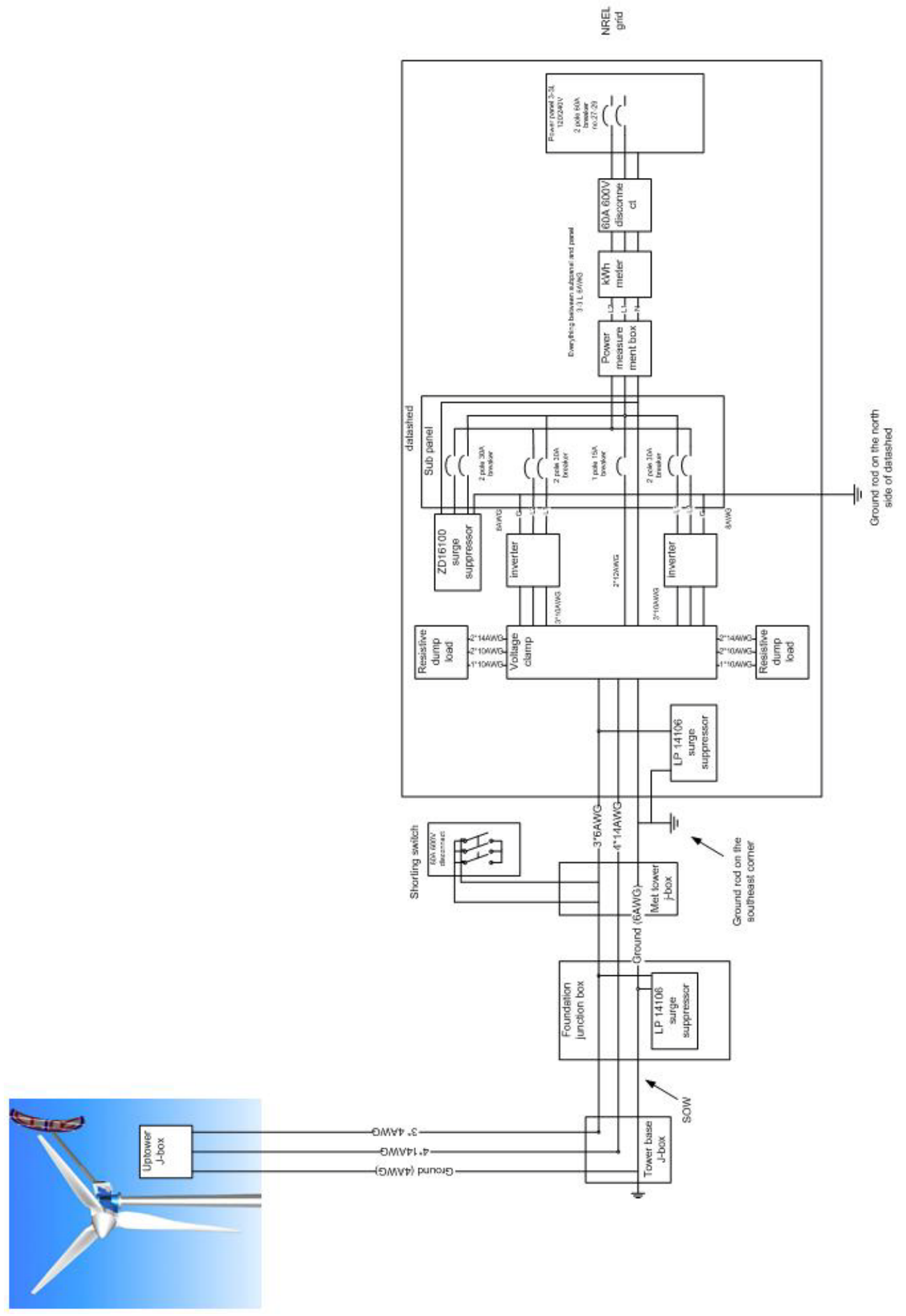

Figure 2. Electrical Drawing of the ARE 442 installation 


\section{Instrumentation}

The following parameters were measured in this test: wind speed, electrical power, rotor speed, and grid voltage. NREL calculated the rotor speed by measuring the frequency of the wild AC (variable voltage, variable frequency) coming from the alternator.

An indication of turbine status was obtained by measuring the status of the relays that activate the brake resistors up in the yaw head. The signal is zero when the generator is shorted, and five when it is not.

The instruments that were used for these measurements are listed in Table 2. The calibration sheets for the instruments used for this safety and function test are included in Appendix A.

Table 2. Equipment List for Safety and Function Test

\begin{tabular}{|l|l|l|l|}
\hline Instrument & Make, Model & $\begin{array}{l}\text { Serial } \\
\text { Number }\end{array}$ & $\begin{array}{l}\text { Calibration Due } \\
\text { Date }\end{array}$ \\
\hline Power transducer & $\begin{array}{l}\text { Secondwind Phaser 5FM- } \\
\text { 4A20 }\end{array}$ & 02663 & April 28, 2009 \\
\hline Current transducers & OSI 12974 & $\begin{array}{l}001235408 \\
001235411\end{array}$ & $\begin{array}{l}\text { Calibrated with } \\
\text { Power transducer, } \\
\text { April 28, 2009 }\end{array}$ \\
\hline Primary anemometer & Thies, First Class & 0707886 & Feb. 28, 2009 \\
\hline $\begin{array}{l}\text { Reference } \\
\text { anemometer }\end{array}$ & NRG, Max 40 & 179500049022 & In situ \\
\hline Rotor speed & $\begin{array}{l}\text { OSI Voltage Transducer VT7- } \\
\text { 010E-11 }\end{array}$ & 08010700 & April 28, 2009 \\
\hline $\begin{array}{l}\text { Data acquisition } \\
\text { system }\end{array}$ & $\begin{array}{l}\text { Compact DAQ w/LabView } \\
\text { based data acquisition } \\
\text { cDAQ-9172 }\end{array}$ & & $\begin{array}{l}12 \mathrm{EAE} 14 \\
12 \mathrm{~A} 2037\end{array}$ \\
& NI 9229 & $\begin{array}{l}\text { May 31, 2008 } \\
\text { Aug. 3, 2008 } \\
\text { Oct. 9, 2008 } \\
\text { NI 9217 }\end{array}$ & 12ECB77 \\
& NI 9205 & $\begin{array}{l}\text { Modules calibrated } \\
\text { post-test on May } \\
6,2009, \text { found in } \\
\text { compliance }\end{array}$ \\
\hline
\end{tabular}




\section{Procedure}

Safety and function testing may involve some risk to personnel and to equipment. NREL endeavors to accomplish its tasks with minimal risk by incorporating appropriate controls into testing procedures. This test report documents these controls where they may have had an influence on results obtained.

\section{Control and Protection System Functions}

The first part of the test procedure is to assess the control and protection system functions listed below. For each function, NREL provided an input to the existing control and protection system or simulated the external condition. NREL then recorded the response of the turbine.

In the list below, turbine response was observed for each major response category (startup, normal shutdown, emergency shutdown). If faults or other actions caused one of these major responses, NREL simulates the appropriate input and verifies that the control and protection system appropriately a) sensed the condition, and b) provided indication of an appropriate response. This procedure enables, for example, all the E-stop functions to be checked without exposing the turbine to multiple, potentially-damaging stops. These checks are designated by the term "behavior" in the list below.

1. Power control

2. Rotor speed control

3. Yaw orientation

4. Startup

a. Normal operation - winds rising above cut-in

b. After maintenance or fault clearance at design wind speed or above

c. Maintenance of fault conditions at design wind speed or above

5. Normal shutdown

6. Emergency shutdown during operation

7. Behavior upon excessive vibration

8. Behavior upon loss of load

9. Turbine specific checks

a. Behavior upon over-temperature

b. Behavior upon loss of load brake or diversion load connection 


\section{Personnel Safety Provisions}

The second part of the test procedure is to evaluate provisions for personnel safety. For this turbine, the following issues were reviewed.

- Safety instructions

- Climbing

- Fire resistance and control

- Fire extinguisher

- Emergency stop buttons

- Lock-out / tag-out provisions

- Interlock on electrical cabinets

- Safety signs

- Unauthorized changing of control settings

- Lightning protection

- Presence and functioning of rotor and yaw lock

\section{Dynamic Behavior}

NREL observed the turbine over a wide range of wind speeds. Observations were written in the logbook and are reported in the results section. No direct measurement of accelerations was done for this turbine.

\section{Results}

Test results reported here are based on test conducted from June 12, 2008 when the turbine was commissioned through October 2, 2009.

\section{Control and Protection System Functions}

The only significant finding is that the rotor speed NREL measured is well above what the manufacturer specified.

NREL limits testing to investigate single-fault failures and has not investigated failures of "safe life" components. If a second fault were to occur during a critical event, severe results can be expected. NREL does not make judgments on whether such failures are likely or whether additional features in the control and protection system are needed to protect against such consequences.

The following is a list of tests that NREL conducted on the ARE 442: 


\section{Power control}

Figure 3 shows that the power output of the turbine system is limited. This is mainly due to the power output limitations of the inverters. It does not necessarily mean that the turbine itself is limiting power correctly. The measured power curve does not deviate significantly from the published power curve.

\section{Rotor speed control}

Rotor speed measurements taken during the test period do not conclusively indicate that the turbine system exhibits control over rotor speed in response to high winds. Figure 4 shows both 10-minute average rotor speed data and maximum and minimum value in each 10 minute period. The maximum and minimum values are based on data samples at $40 \mathrm{~Hz}$. The averages appear to be leveling off quite well. However, there is quite a bit of variation in the maxima with no clear trend. Most of the high maxima were measured during periods where the turbine came back online from a faulted condition during high wind conditions. An example of such a high rotor speed event is given in Figure 5.

The manufacturer's expected maximum rotor speed was “above 200 rpm."

\section{Yaw orientation}

NREL observed yaw behavior frequently during the test period and compared yaw position with the nearby wind-vane indication of wind direction. We observed normal behavior under all wind conditions. At low wind speeds, the rotor operates at about $40^{\circ}$ offset from the prevailing wind direction. This yaw error decreases as the wind speed increases until the turbine furls.

This turbine uses slip rings to transmit power to and from the nacelle to the tower cable. Therefore, droop cable over-twist is not an issue.

\section{Startup}

NREL observed that the turbine rotor starts spinning whenever winds increase to about $2 \mathrm{~m} / \mathrm{s}$. The turbine controller responds after a wait period during which it checks brake functionality. This is followed by a period during which the controller keeps the rotor speed at a low value until the inverters come on-line. When the inverters are online, the controller releases the rotor to normal operating speed. NREL has observed the turbine starting up over a wide range of wind speeds. NREL has not observed any abnormal behavior during any of the startups. NREL observed similar smooth cut-ins when the turbine was returned to service after shutdown.

\section{Normal Shutdown}

When winds drop below cut-in, the rotor gradually slows and stops producing power with no significant change in sound or behavior. This turbine does not have a cut-out wind speed, so normally it does not shut down in high winds.

\section{Emergency shutdown during operation from any operating condition}

Physically the emergency shutdown is the same as an automatic shutdown due to a fault. 
The turbine safely brings the rotor down to an idling speed under any wind condition. This behavior is consistent with the manual's statement that the system can be shut down at any wind speed.

In addition to the automatic shutdown the controller performed, NREL also performed shutdowns by pushing the stop button on the voltage clamp. The turbine safely brought the rotor down to an idling speed any time this was performed.

\section{Behavior upon excessive vibration}

The turbine has no means to sense excessive vibration or to shut down should excessive vibration occur. The IEC turbine design standards require such sensors on large turbines but not on turbines smaller than $200^{\mathrm{m} 2}$.

\section{Behavior upon loss of load}

When the inverters sense a grid fault, they disconnect from the grid. The voltage clamp then applies the brake. NREL tested for this by opening the disconnect switch between the ARE subpanel and panel 3-3L. This test took place on November 5, 2008 in winds of about $12 \mathrm{~m} / \mathrm{s}$.

The turbine shut down but then never came back online. It was found that the Insulated Gate Bipolar Transistors IGBT's in the voltage clamp had failed. Figure 6 shows the time traces of the event.

A similar event during which the IGBT's failed happened during a real grid outage on June 13th. Both failures happened during winds in which the inverters were producing maximum power and the diversion loads were likely already active.

On July 20, 2009, the loss of load simulation was repeated in low winds $(6 \mathrm{~m} / \mathrm{s})$. The turbine did not sustain any damage from this test. (Figure 7)

\section{Turbine specific checks}

\section{Over temperature}

This turbine system has provisions to monitor temperature in the voltage clamp and in the diversion loads. Should those components become too hot, the turbine shuts down, initiates a 5-minute cool down period, and waits until all temperatures are below their set point. On December 5, 2008, independent temperature readings were taken during high winds. At the time, an over-temperature fault occurred. NREL measured the temperature at the top of one of the diversion loads to be $72.7^{\circ} \mathrm{C}$. The temperature in the voltage clamp enclosure was $41.2^{\circ}$. At that time, the ambient temperature in the data shed was $34.4^{\circ} \mathrm{C}$.

\section{Load brake resistor failure simulation}

Upon startup of the turbine, the voltage clamp checks to see if the diversion loads and brake resistors are properly installed. To test this function, NREL disconnected the DL2+ wire inside the voltage clamp. The turbine went through the startup sequence, allowing the rotor to rotate slowly. It then faulted to a Load/Brake Resistor test fault as indicated by the red and green LED both being steady on. 


\section{Personnel Safety Provisions}

\section{Safety Instructions}

The turbine operator's manual provides few safety instructions for installation, operation, and maintenance. The turbine does not require trained personnel for maintenance or servicing so no warning of this nature is required on the manual's cover.

The Owners manual covers assembly of the turbine but not the actual installation of the turbine system. NREL asked and received a separate document describing the installation procedure including hoisting and rigging information.

NREL checked the manual to determine if the safety instructions addressed requirements in the IEC small turbine design standard and found the following:

1. Disengage the load and/or energy sources: The voltage clamp has instructions indicating that it should only be opened after the stop button has been pushed. The inverter manuals describe how to disconnect the inverters from both the DC and $\mathrm{AC}$ connections.

2. Stop and secure the rotor: NREL found an explanation on how to slow down the rotor but no provision was found on how to stop it completely.

3. Stop and secure the yaw mechanism: The turbine has no provisions for securing the yaw mechanism.

4. Stop and secure the furling system: The turbine has no provisions for securing the furl mechanism.

5. Climb tower: The tower came with a TUF TUG safety climb system. It included a manual with instructions for safe climbing.

\section{Climbing}

NREL personnel climbed the turbine using the supplied TUF TUG fall protection system. On one side of the tower, additional horizontal braces are installed to form a ladder. Climbing the tower was found to be fairly easy. The main issue was getting to a working position at the top of the climbing system. There are no recommendations in the owner's manual about transferring from the fall protection cable to a working position on the turbine and the climbing system ends before reaching a position high enough to work on the turbine. There are no obvious or clearly identified tie off points other then the tab on top of the turbine behind the rotor, which is difficult to reach when still holding on to the side of the ladder. Another issue is preventing the turbine from yawing while in the process of getting into a working position. NREL recommends inserting some language into the manual describing how to safely tie off a blade to the tower to prevent rotor rotation and yaw movement. 


\section{Fire resistance and control}

The Windyboy inverters are designed to resist "normal internal temperatures" and according to the manual will de-rate to maintain safe internal temperatures. NREL did not evaluate this since the inverter is UL listed as compliant with UL 1741.

The voltage clamp has a temperature sensor which will shut the turbine down once the temperature exceeds a threshold. The dump load is enclosed in a fire-resistant, metal enclosure. It has temperature sensors installed in the top of the enclosures. If the temperature exceeds the limits, the turbine will shut down.

The turbine Owner's Manual describes the clearance required around each of the system's components.

\section{Fire extinguisher}

NREL provided a fire extinguisher in the building that housed the voltage clamp, diversion loads, and inverters. The manufacturer does not provide fire extinguishers or recommend that they be installed.

\section{Emergency Stop Button}

The turbine has an emergency stop button on the voltage clamp (Figure 8) for use in manual turbine shutdown.

\section{Lock-out / tag-out provisions}

NREL provided a lockable switch between the grid and the subpanel that was connected to the voltage clamp and the inverters (Figure 9). The manufacturer does not provide this equipment or recommend that this type of equipment be installed. Nor does the manufacturer provide procedures for de-energization of the turbine system.

\section{Interlock on electrical cabinets}

The voltage clamp does not have an interlock on the cabinet. However, there is a warning label and instructions on the door. A hex key is needed to open the cabinet.

\section{Safety signs}

1. The voltage clamp has a label warning of high voltage and instructions on how to safely open the enclosure. (Figure 10)

2. The diversion loads did not have any warning signs. NREL added a sign stating "Caution hot surface do not touch."

3. The TUF TUG safety system has a tag on the cable at the base of the tower. (Figure 11)

4. NREL added labels indicating the voltage levels on all enclosures, electrical panels, and disconnects.

\section{Unauthorized changing of control settings}

There are no readily accessible ways to alter any settings in the voltage clamp. The inverter settings can be changed if the directions in the manual are followed. The inverter must be opened to do so. 


\section{Lighting Protection}

The turbine was purchased with the lightning protection package. This is normally an add-on that has to be purchased separately. It consists of three surge suppressors. One at the tower base, one on the voltage clamp, and one on the sub-panel as indicated in Figure 2. During the test period, no direct or nearby lightning strikes were observed.

In addition to the surge suppressors, the turbine base is grounded and a ground wire runs in the trench back to the data shed to a second ground rod. No Ufer ground was specified for the foundation itself.

\section{Presence of rotor and yaw lock}

There is no rotor lock or yaw lock present on the turbine.

\section{Dynamic Behavior}

NREL observed operation throughout the test period in wind speeds ranging from dead calm to winds in excess of $25 \mathrm{~m} / \mathrm{s}$. The total observation time exceeded the required one hour. NREL did not measure accelerations directly. NREL noted that the turbine displayed no excessive vibrations. The turbine did not produce any significant differences in noise levels. Tail movement and yaw behavior appeared normal under all conditions.

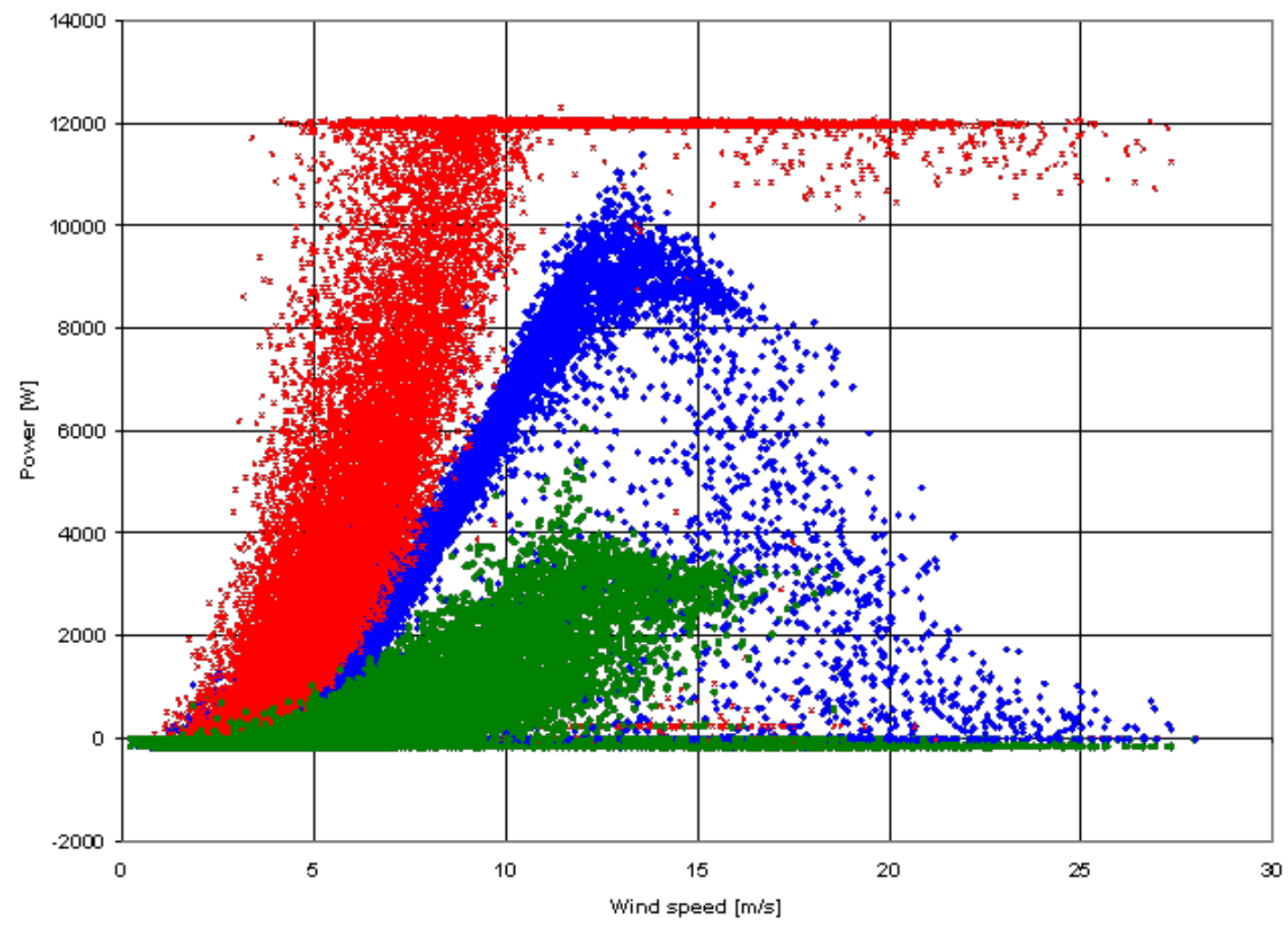

Figure 3. Power response to wind speed (red-maxima, green - minima, blue -average) 


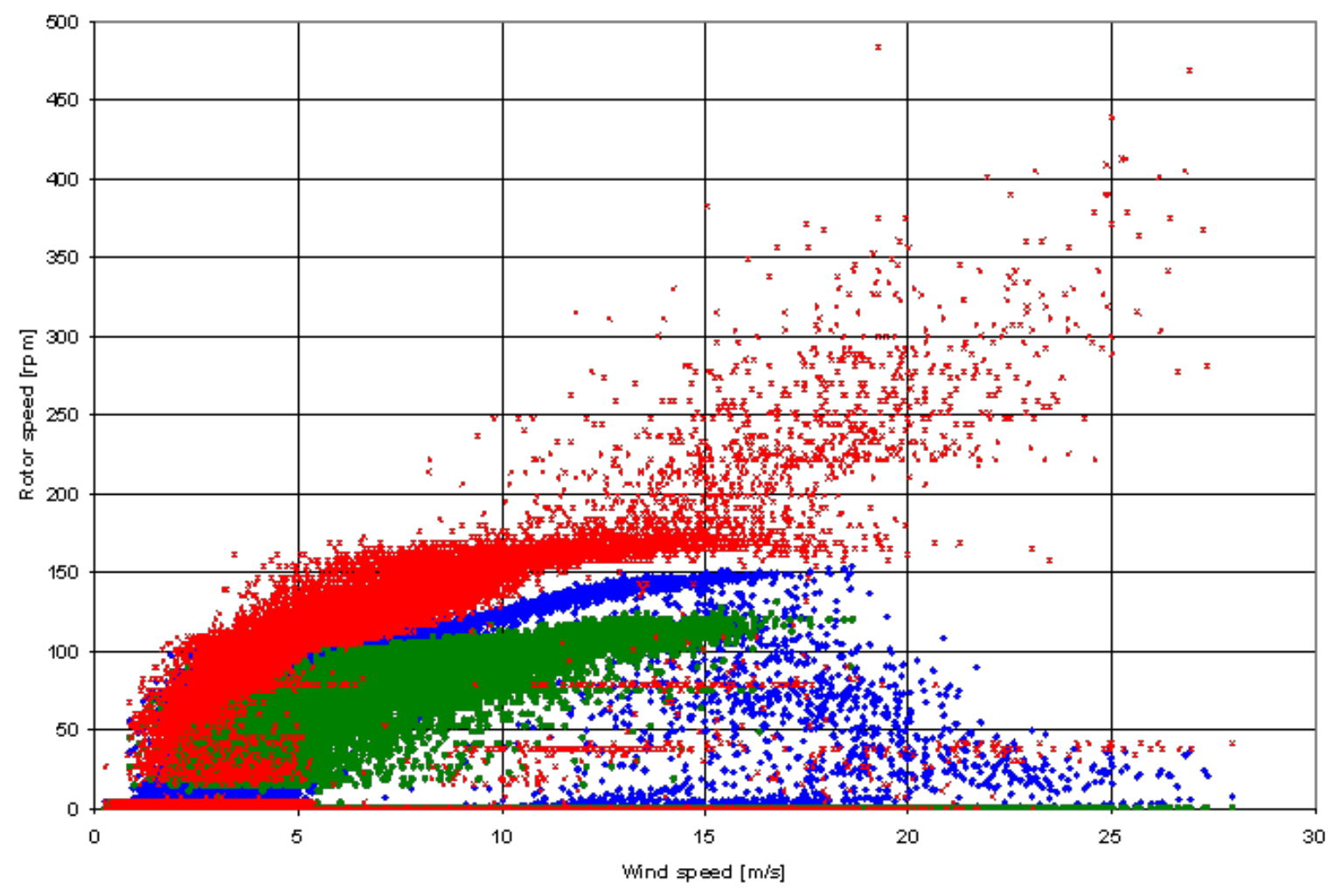

Figure 4. Rotor speed response to wind speed (red- maxima, green - minima, blue -average) 

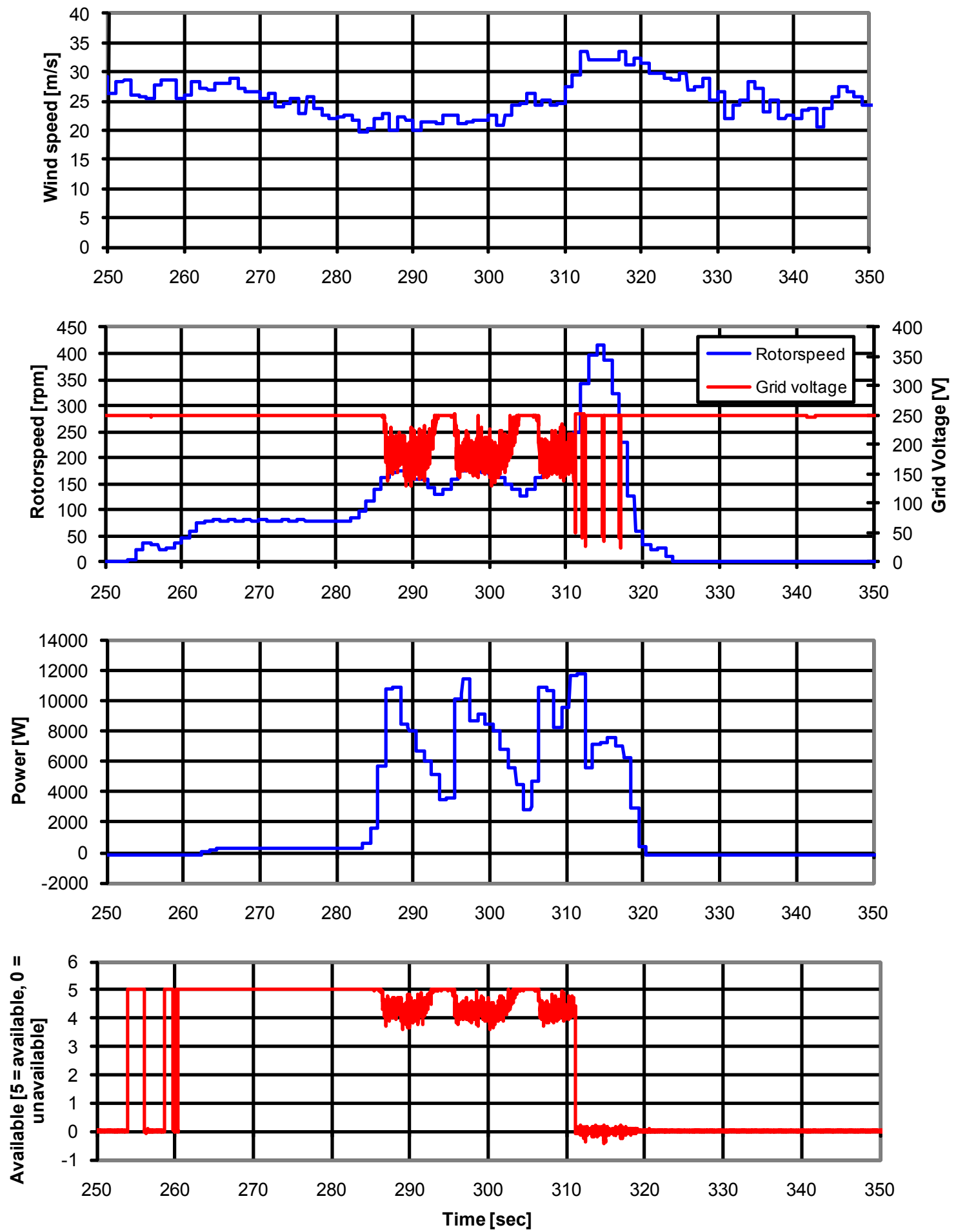

Figure 5. Time series of a high rpm event (datafile ARE081230_001156) 

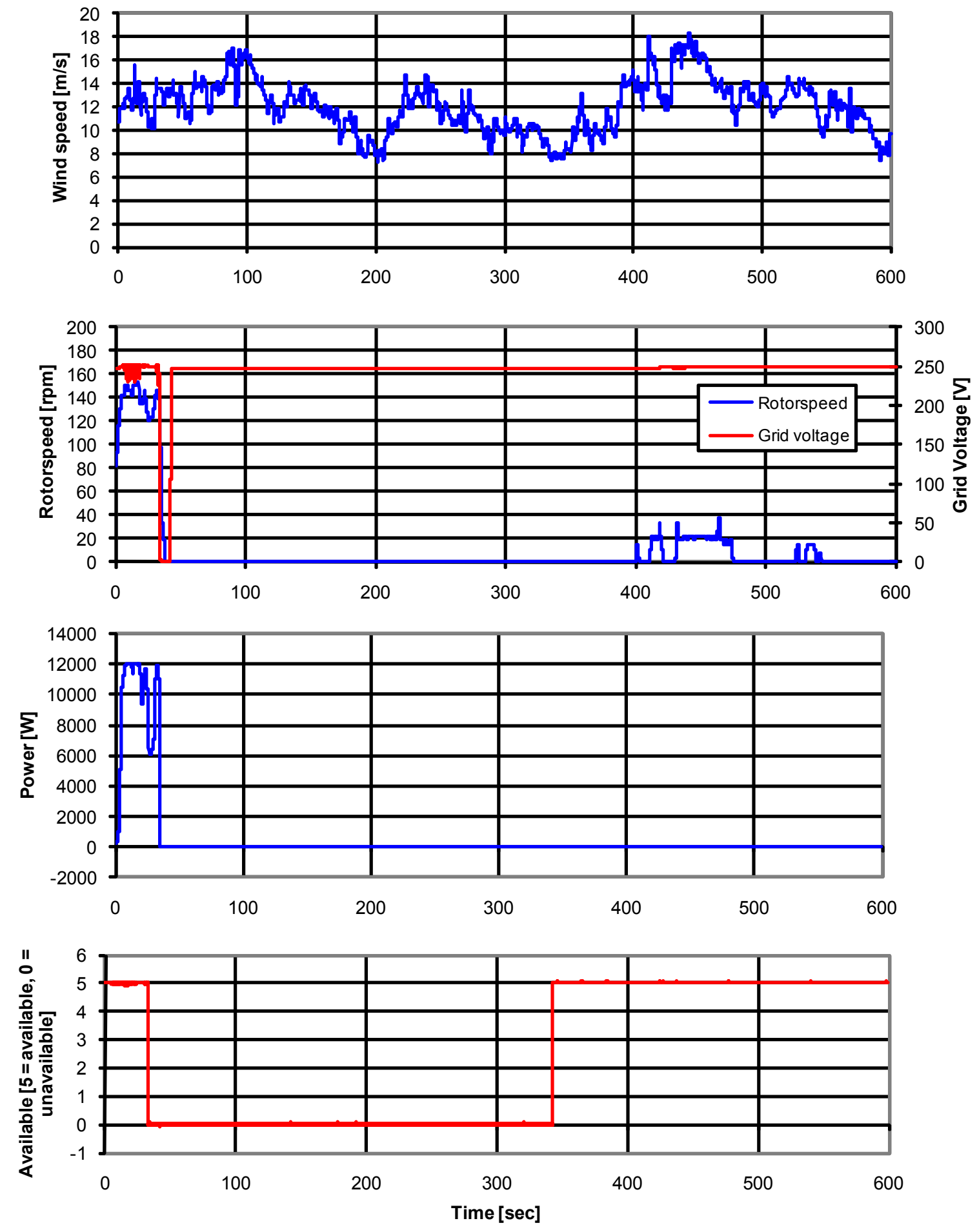

Figure 6. Turbine response during a simulated grid outage -- the IGBT's failed. (datafile ARE081105_144425) 

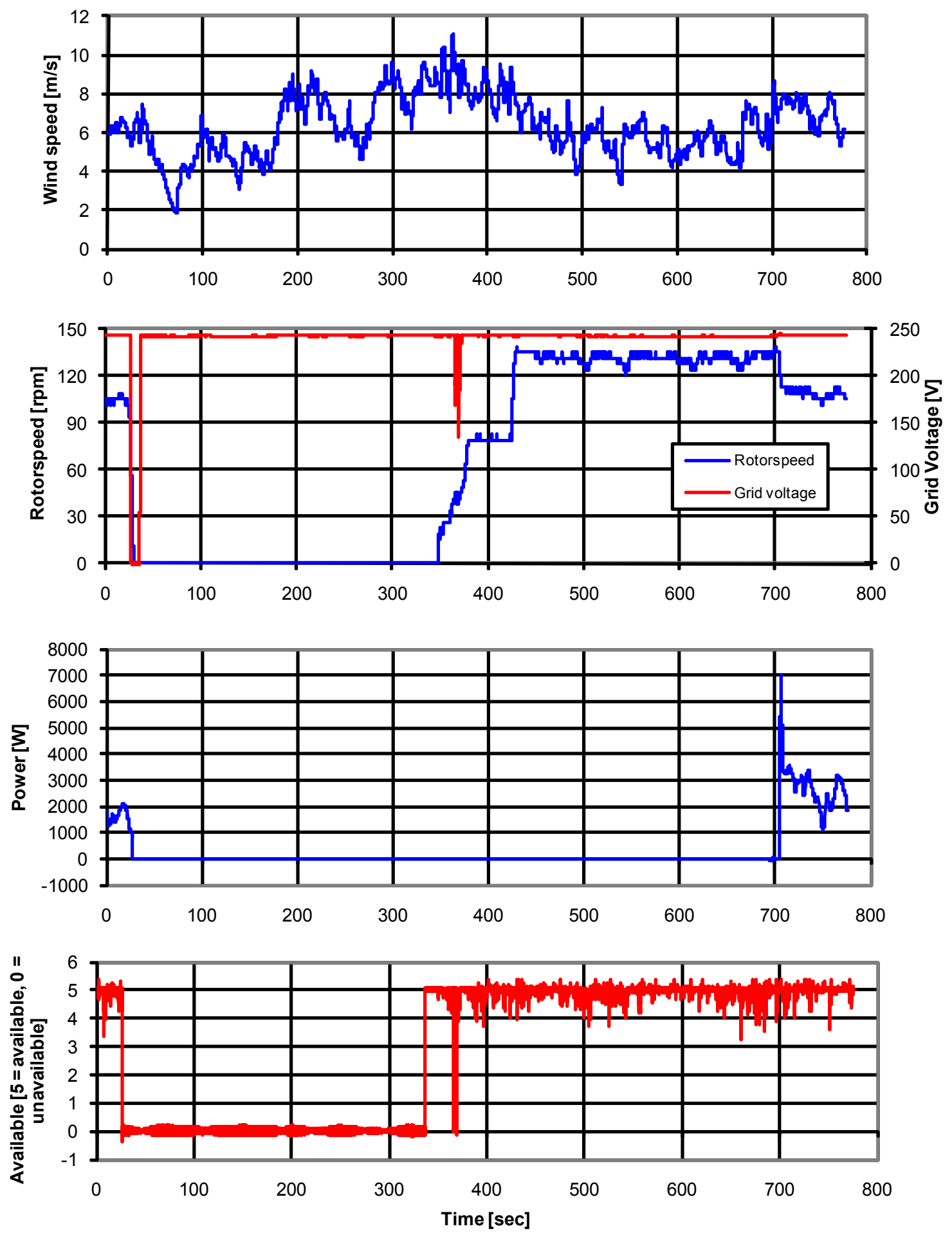

Figure 7. Simulated grid outage in low winds (data file ARE090720_115146) 


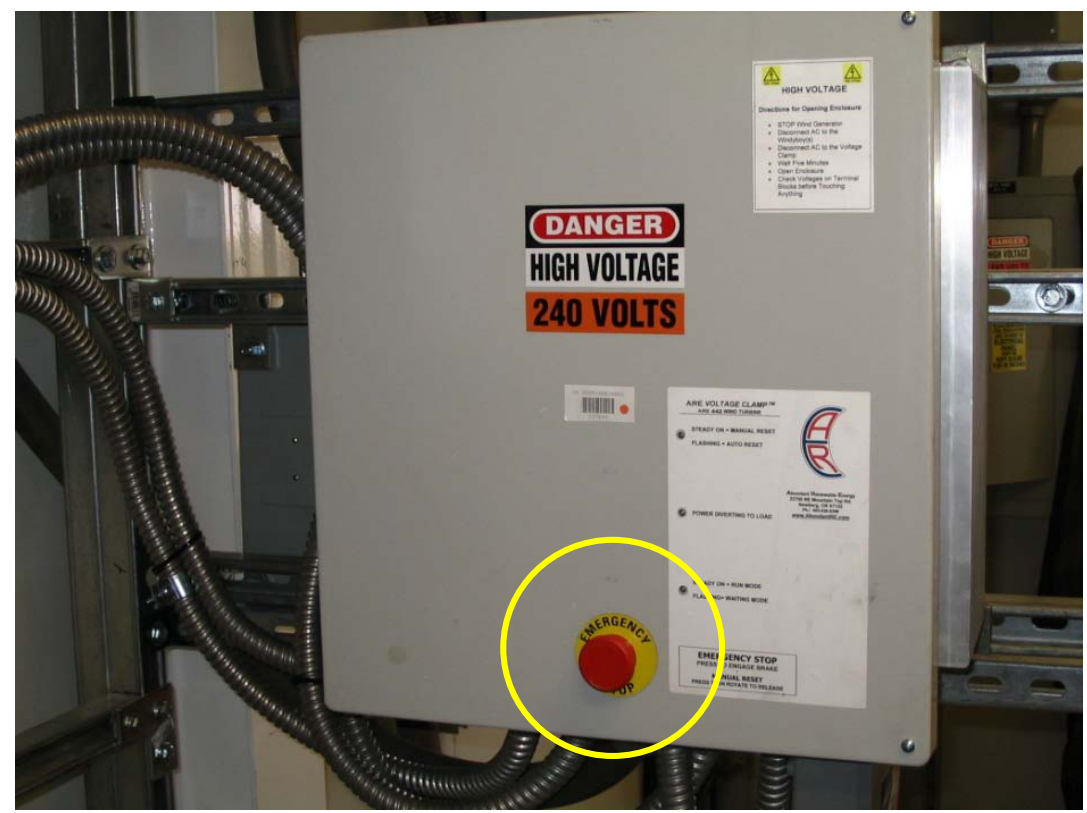

Figure 8. ARE442 Voltage clamp with e-stop button 


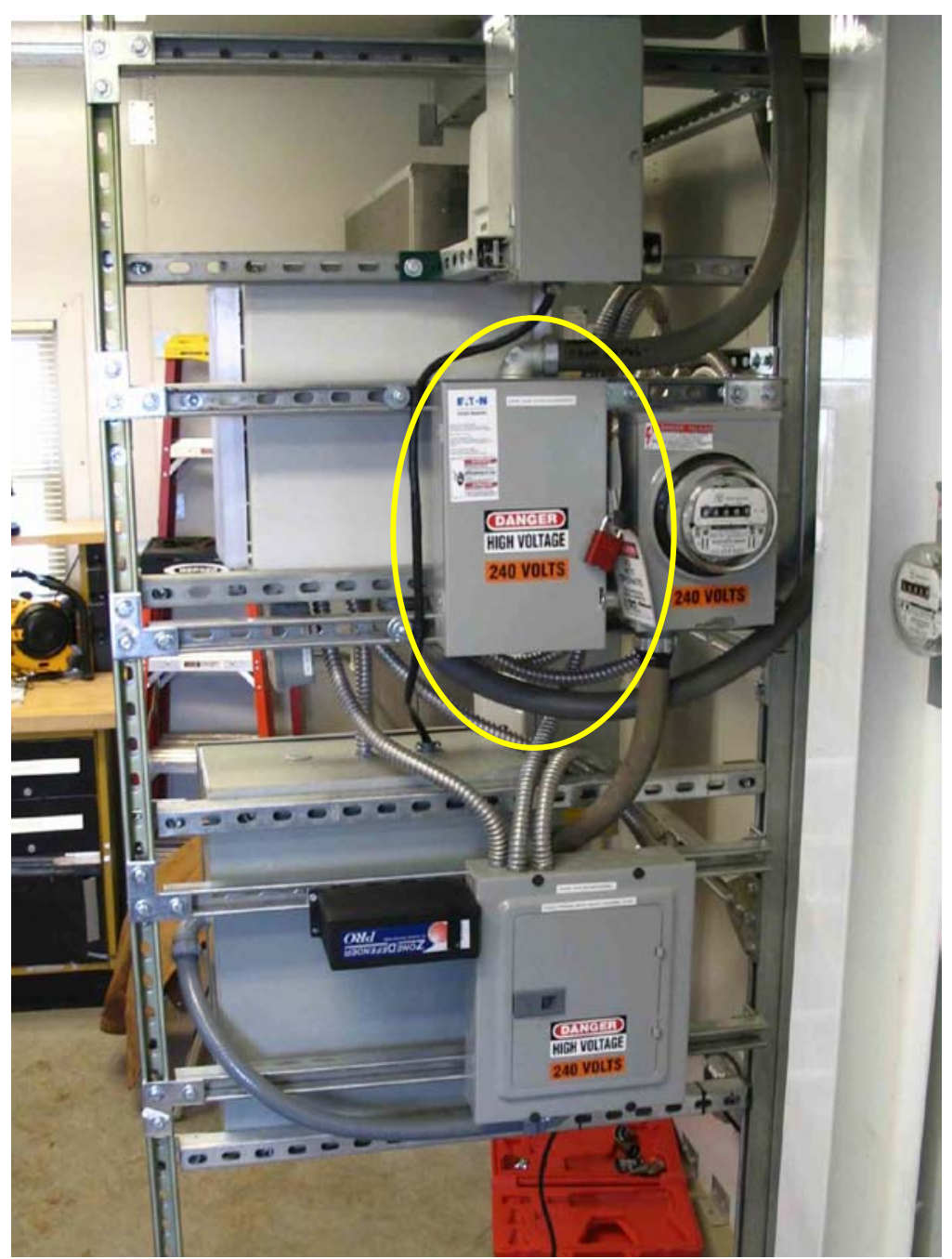

Figure 9. ARE 442 disconnect 


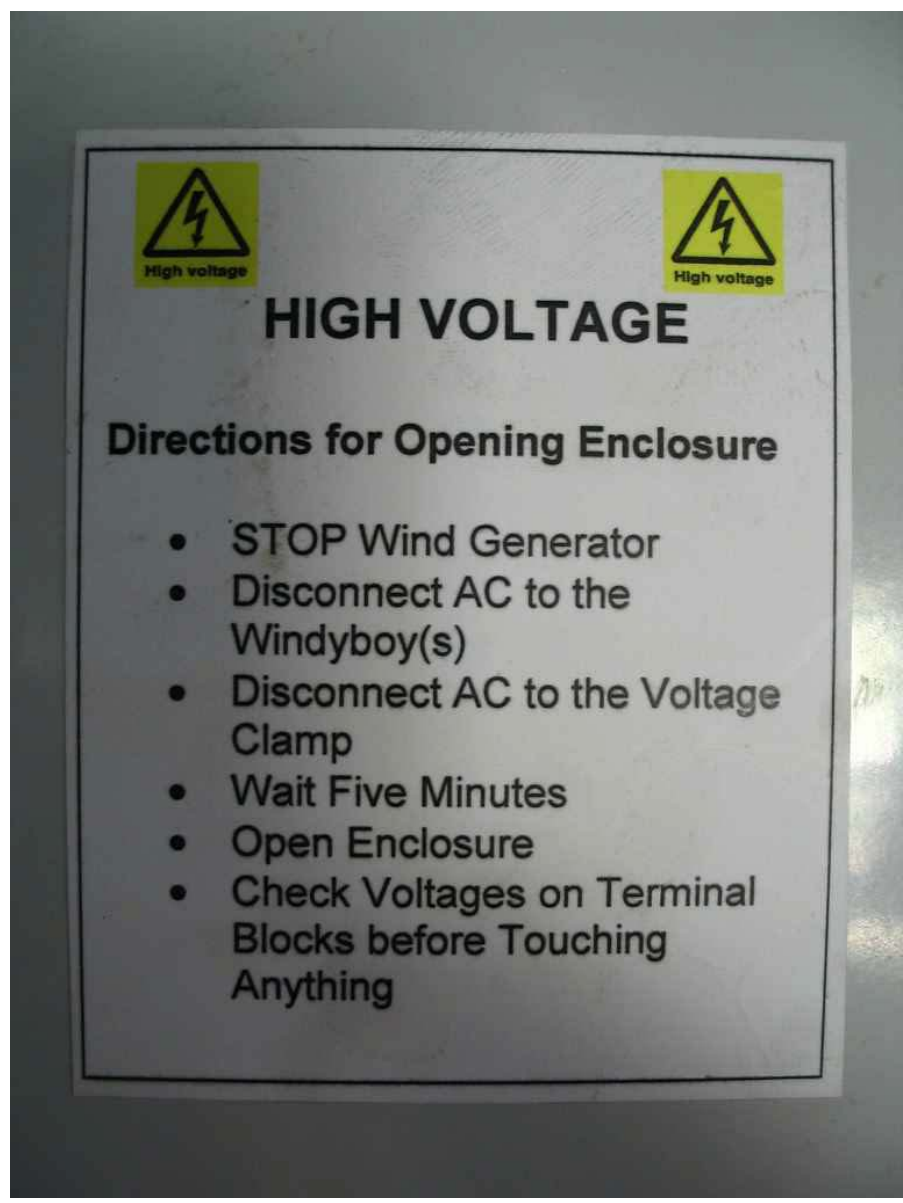

Figure 10. Safety instructions on the voltage clamp 


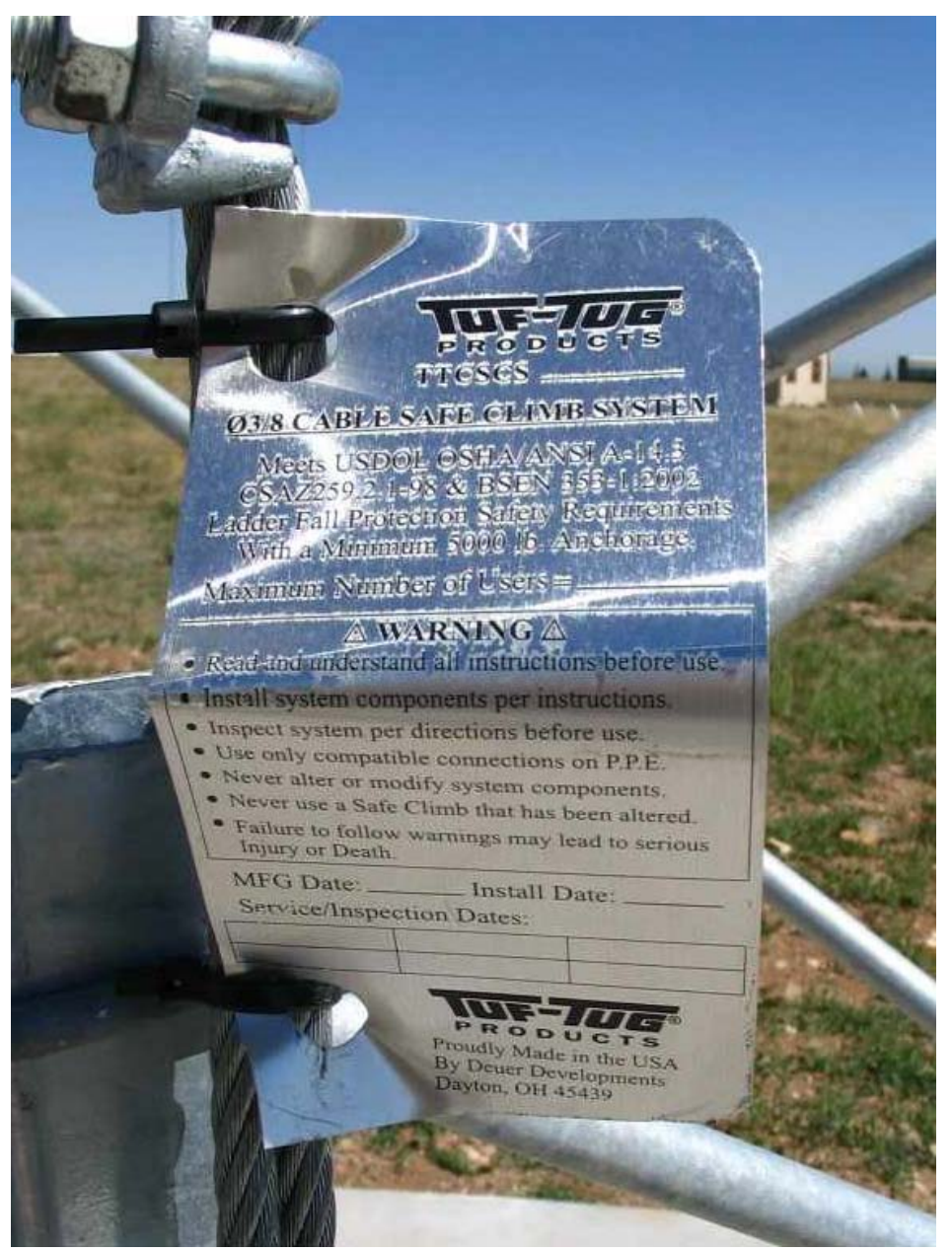

Figure 11. Safety instruction tag on the TUF TUG climbing system

\section{Deviations and Exceptions}

\section{Deviations from the Standard}

There were no known exceptions to the Standard for the test.

\section{Exceptions to the NWTC Quality Assurance System}

The data acquisition modules were used beyond the calibration due date. The modules were post-test calibrated and found to be in compliance within the specifications. Appendix A includes the post-test calibration sheets. 


\section{Appendix A - Instrument Calibration Sheets}

Branch \#: 5000

\section{NREL METROLOGY LABORATORY}

Test Report

Test Instrument: Phaser Power Transducex \& 2-CTs

DOE \# : $02824 C$

Model \#

- Phasex-5-F-5A

$S / N \quad: 02663$

Calibration Date: 01/28/2008

Due Date: $01 / 28 / 2010$

A. Set-Up for Total Real Power Calibration:

A.1. Voltage is applied to phases $A \& B=120 \mathrm{~V}$ a $60 \mathrm{~Hz}$

A.2. Current is applied to $n=5$-TURNS through two current transformers

that are connected to phases $A \& B$.

A.3. Analog Output-1 is measured across precision resistor $=250 \Omega$.

A.4. Phaser Full scale setting $=-7.2 \mathrm{KW}$ to $7.2 \mathrm{KW}$.

\begin{tabular}{|c|c|c|}
\hline $\begin{array}{c}\text { Input Current } \\
(A A C)\end{array}$ & Input Power & Analog Output-1 \\
(vDC)
\end{tabular}

B. Set-Up for Power Factor Calibration:

B.1. Voltage \& Current are applied as A.1 \& A.2.

B.2. Analog Output-2 is measured across precision resistor $=250 \Omega$.

\begin{tabular}{|c|c|c|}
\hline $\begin{array}{c}\text { Power } \\
(\mathrm{KW})\end{array}$ & Power Factor & $\begin{array}{c}\text { Analog Output-2 } \\
\text { (VDC) }\end{array}$ \\
\hline 6.72 & 1.0 & 4.989 \\
\hline$"$ & 0.8 & 4.179 \\
\hline$"$ & 0.6 & 3.377 \\
\hline$n$ & 0.4 & 2.577 \\
\hline$"$ & 0.2 & 1.778 \\
\hline
\end{tabular}

Page 1 of 2

Figure A.1. Power transducer calibration sheet 


\section{DEUTSCHER KALIBRIERDIENST DKD}

Kalibrierlaboratorium für Strömungsgeschwindigkeit von Luft Calibration laboratory for velocity of air flow

Akkreditiert durch die / accredited by the

Akkreditierungsstelle des DKD bei der PHYSIKALISCH-TECHNISCHEN BUNDESANSTALT (PTB)

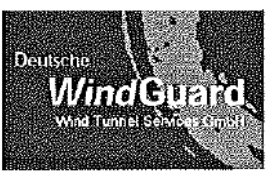

Kalibrierschein

Calibration Certificate

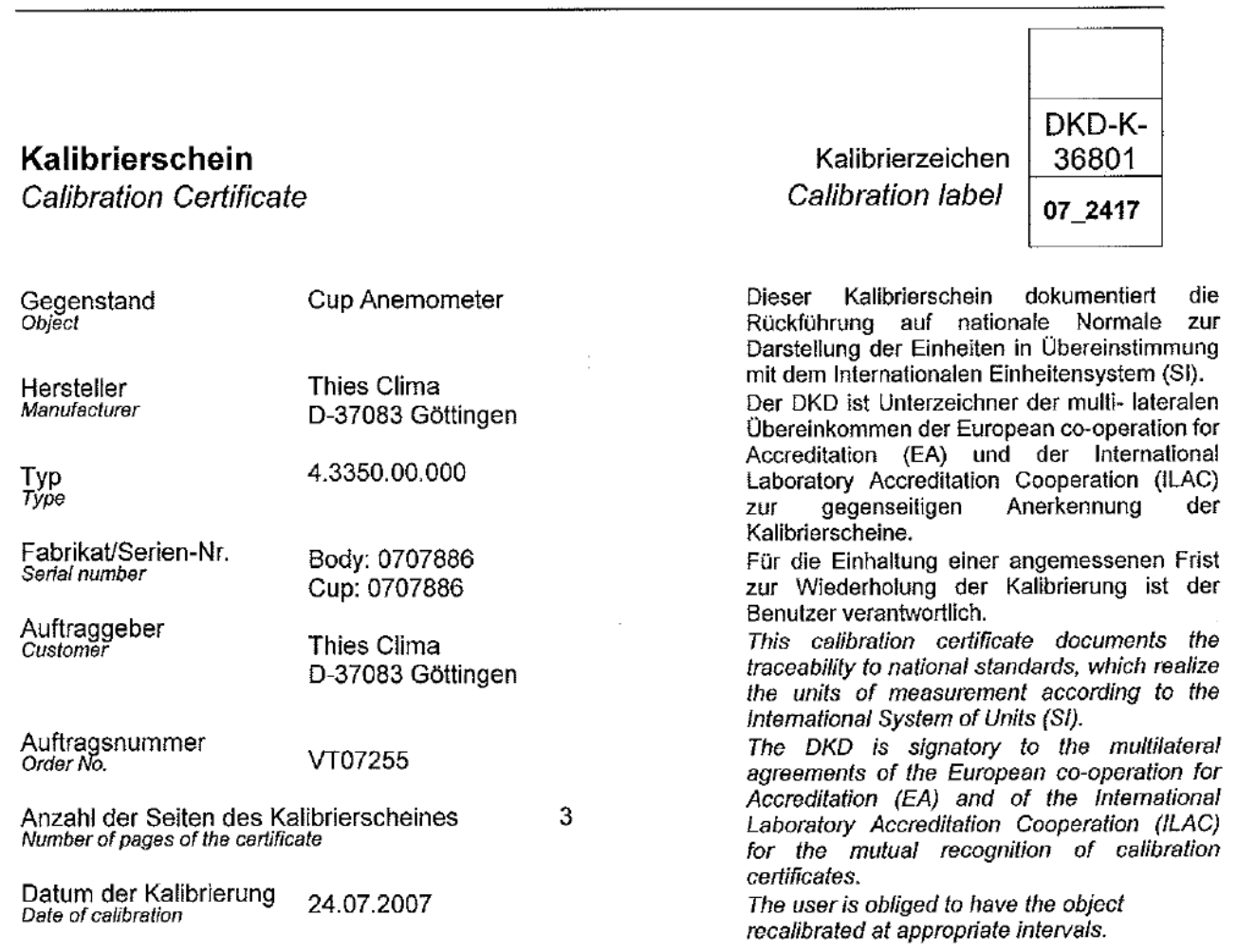

\author{
Deutsche WindGuard \\ Wind Tunnel Services $\mathrm{GmbH}$ \\ Varel
}

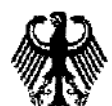

Dieser Kalibrierschein darf nur vollständig und unverändert weiterverbreitet werden. Auszüge oder Änderungen bedürfen der Genehmigung sowohl der Akkreditierungsstelle des DKD als auch des ausstellenden Kalibrierlaboratoriums. Kalibrierscheine ohne Unterschrift und Stempel haben keine Gültigkeit.

This calibration certificate may not be reproduced other than in full except with the permission of both the Accreditation Body of the DKD and the issuing laboratory. Calibration certificates without signature and seal are not valid.

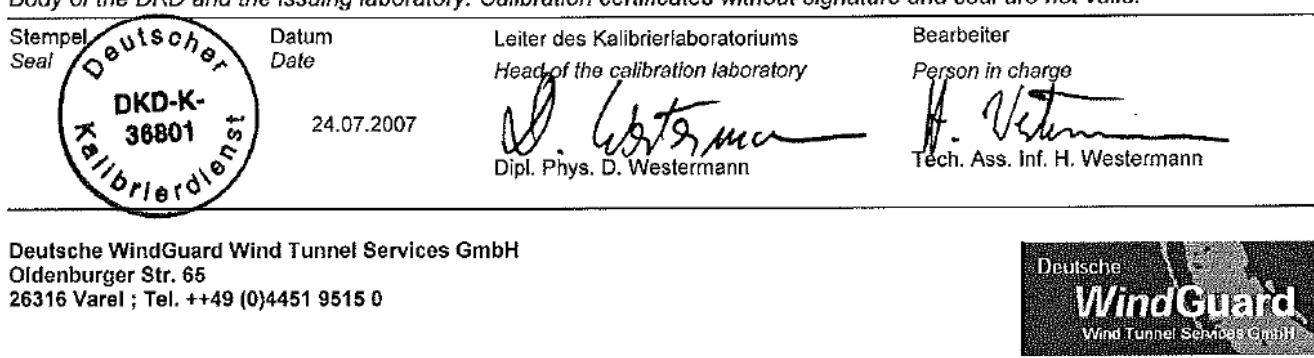

Figure A.2. Primary anemometer calibration sheet 
Board Information:

Serial Number: 12A2037

NI Part Number: 192580D-02

Description: NI 9229

Calibration Date: 31-MAY-07

Recommended Calibration Due Date: $31-\mathrm{MAY}-08^{*}$

Ambient Temperature: $22{ }^{\circ} \mathrm{C}$

Relative Humidity: $50 \%$
Certificate Information:

Certificate Number: 733748

Date Printed: 05-JAN-09

National Instruments certifies that at the time of manufacture, the above product was calibrated in accordance with applicable National Instruments procedures. These procedures are in compliance with relevant clauses of ISO 9001 and are designed to assure that the product listed above meets or exceeds National Instruments specifications.

National Instruments further certifies that the measurements standards and instruments used during the calibration of this product are traceable to National and/or International Standards administered by NIST or Euromet members or are derived from accepted values of natural physical constants.

The environment in which this product was calibrated is maintained within the operating specifications of the instrument and the standards.

The information shown on this certificate applies only to the instrument identified above and the certificate may not be reproduced, except in full, without prior written consent by National Instruments.

For questions or comments, please contact National Instruments Technical Support.

NI Hungary Software és Hardware Gyártó Kft. 4031 Debrecen, Határ út $1 / A$. HUNGARY
Signed,

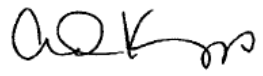

Andrew Krupp Quality Director

* Recommended calibration due date is based on a combination of calibration interval and, when applicable, calibration shelf life. This date may vary depending on your application requirements.

Figure A.4. NI 9229 data acquisition module calibration sheet I 
Board Information:

Serial Number: 12C73B4

NI Part Number: 192547D-01

Description: NI 9217

Calibration Date: 03-AUG-07

Recommended Calibration Due Date: 03-AUG-08*

Ambient Temperature: $23{ }^{\circ} \mathrm{C}$

Relative Humidity: $46 \%$
Certificate Information:

Certificate Number: 786529

Date Printed: 05-JAN-09

National Instruments certifies that at the time of manufacture, the above product was calibrated in accordance with applicable National Instruments procedures. These procedures are in compliance with relevant clauses of ISO 9001 and are designed to assure that the product listed above meets or exceeds National Instruments specifications.

National Instruments further certifies that the measurements standards and instruments used during the calibration of this product are traceable to National and/or International Standards administered by NIST or Euromet members or are derived from accepted values of natural physical constants.

The environment in which this product was calibrated is maintained within the operating specifications of the instrument and the standards.

The information shown on this certificate applies only to the instrument identified above and the certificate may not be reproduced, except in full, without prior written consent by National Instruments.

For questions or comments, please contact National Instruments Technical Support.

NI Hungary Software és Hardware Gyártó Kft.

4031 Debrecen, Határ út

$1 / A$.

HUNGARY
Signed,

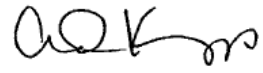

Andrew Krupp

Quality Director

* Recommended calibration due date is based on a combination of calibration interval and, when applicable, calibration shelf life. This date may vary depending on your application requirements.

Figure A.5. NI 9217 data acquisition module calibration sheet I 
Board Information:

Serial Number: 12ECB77

NI Part Number: 193299F-01

Description: NI-9205

Calibration Date: 09-OCT-07

Recommended Calibration Due Date: 09-OCT-08*

Ambient Temperature: $23{ }^{\circ} \mathrm{C}$

Relative Humidity: $37 \%$
Certificate Information:

Certificate Number: 837236

Date Printed: 05-JAN-09

National Instruments certifies that at the time of manufacture, the above product was calibrated in accordance with applicable National Instruments procedures. These procedures are in compliance with relevant clauses of ISO 9001 and are designed to assure that the product listed above meets or exceeds National Instruments specifications.

National Instruments further certifies that the measurements standards and instruments used during the calibration of this product are traceable to National and/or International Standards administered by NIST or Euromet members or are derived from accepted values of natural physical constants.

The environment in which this product was calibrated is maintained within the operating specifications of the instrument and the standards.

The information shown on this certificate applies only to the instrument identified above and the certificate may not be reproduced, except in full, without prior written consent by National Instruments.

For questions or comments, please contact National Instruments Technical Support.

NI Hungary Software és

Hardware Gyártó Kft.

4031 Debrecen, Határ út

$1 / A$.

HUNGARY
Signed,

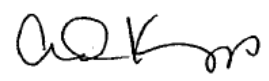

Andrew Krupp

Quality Director

* Recommended calibration due date is based on a combination of calibration interval and, when applicable, calibration shelf life. This date may vary depending on your application requirements.

Figure A.6. NI 9205 data acquisition module calibration sheet I 
Davis|Calibration

Company ID: 229037

NATIONAL INSTRUMENTS

11500 N. MOPAC EXPWY

ATTN. RMA DEPT.

AUSTIN, TX 78759

Instrument ID: 12A2037

Manufacturer: NATIONAL INSTRUMENTS

Description: 4-CHANNEL, \pm 60 V, 24-BIT SIMULTANEOUS ANALOG INPUT

Accuracy: Mfr Specifications

Instrument Identification

\section{Certificate of Calibration}

3214191

Certificate Page 1 of 1

PO Number: 337683

Model Number: NI 9229

Serial Number: 12A2037

Certificate Information

Reason For Service: CALIBRATION

Type of Cal: ACCREDITED 17025

As Found Condition: IN TOLERANCE

As Left Condition: LEFT AS FOUND

Procedure: NATIONAL INSTRUMENTS CAL EXECUTIVE REV 3.3.1

Remarks: Reference attached Data.
Technician: WAYNE GETCHELL

Cal Date 06May2009

Cal Due Date: 06May2010

Interval: 12 MONTHS

Temperature: $23.0 \mathrm{C}$ Humidity: $44.0 \%$

The instrument on this certification has been calibrated against standards traceable to the National Institute of Standards and Technology (NIST) or other recognized national metrology institutes, derived from ratio type measurements, or compared to nationally or internationally recognized consensus standards.

A test uncertainty ratio (T.U.R) of 4:1 [K=2, approx. $95 \%$ Confidence Level] was maintained unless othenwise stated.

Davis Calibration Laboratory is certified to ISO 9001:2000 by Eagle Registrations (certificate \#3046). Lab Operations meet the requirements of ANSINCSL Z540-1-1994, ISO 10012:2003, 10CFR50 AppxB, and 10CFR21.

ISOIEC 17025-2005 accredited calibrations are per ACLASS certificate \#AC-1187 within the scope for which the lab is accredited. All results contained within this certification relate only to item(s) calibrated. Any number of factors may cause the calibration item to drift out of calibration before the instrument's calibration intenval has expired.

This certificate shall not be reproduced except in full, without written consent of Davis Calibration Laboratory.

Approved By: VICTOR PENA

Service Representative

Calibration Standards

\begin{tabular}{|c|c|c|c|c|c|}
\hline NIST Traceable\# & Inst. ID\# & Description & Model & Cal Date & Date Due \\
\hline 3143038 & $15-0271$ & MULTIFUNCTION CALIBRATOR & $5700 \mathrm{~A}$ & 15Apr2009 & 14Jul2009 \\
\hline
\end{tabular}

Davis Calibration • 2324 Ridgepoint Drive, Suite D • Austin, TX 78754 • Phone: 800-365-0147 • Fax: 512-926-8450

Figure A.7. NI 9229 data acquisition module calibration sheet II 


\section{Davis Calibration}

Company ID: 229037

NATIONAL INSTRUMENTS

11500 N. MOPAC EXPWY

ATTN. RMA DEPT.

AUSTIN, TX 78759

Instrument ID: 12C73B4

Manufacturer: NATIONAL INSTRUMENTS

Description: 4-CH 100 OHM 24-BIT RTD ANALOG INPUT

Accuracy: Mfr. Specifications

\section{Certificate of Calibration}

3214178

CREDITED

CALIBRATION

Certificate Page 1 of 1

Instrument Identification

PO Number: 337683

Model Number: NI 9217

Serial Number: 12C73B4

Certificate Information

Reason For Service: CALIBRATION

Type of Cal: ACCREDITED 17025

As Found Condition: IN TOLERANCE

As Left Condition: LEFT AS FOUND

Procedure: CAL EXEC 3.3.1 CAL EXEC 3.3.1

Remarks: Reference attached data.
Technician: WAYNE GETCHELL

Cal Date 06May2009

Cal Due Date: 06May2010

Interval: 12 MONTHS

Temperature: $23.0 \mathrm{C}$

Humidity: $46.0 \%$

Approved By: VICTOR PENA

Service Representative

\begin{tabular}{|c|c|c|c|c|c|}
\hline \multicolumn{6}{|c|}{ Calibration Standards } \\
\hline NIST Traceable\# & Inst. ID\# & Description & Model & Cal Date & Date Due \\
\hline 3078982 & $15-0011$ & DECADE RESISTOR & DB52 & 24Mar2009 & $24 \mathrm{Mar} 2010$ \\
\hline 3004176 & $15-0060$ & DIGITAL MULTIMETER (GOLDEN CAL) & 3458A OPT 002 & 17Feb2009 & 17 May 2009 \\
\hline
\end{tabular}

Davis Calibration • 2324 Ridgepoint Drive, Suite D • Austin, TX 78754 • Phone: 800-365-0147 • Fax: 512-926-8450

Figure A.8. NI 9217 data acquisition module calibration sheet II 


\section{Davis Calibration}

Company ID: 229037

NATIONAL INSTRUMENTS

11500 N. MOPAC EXPWY

ATTN. RMA DEPT

AUSTIN, TX 78759

Instrument ID: 12ECB77

Manufacturer: NATIONAL INSTRUMENTS

Description: $32-\mathrm{CH} \pm 200 \mathrm{MV}$ TO $\pm 10 \mathrm{~V}, 16$-BIT, $250 \mathrm{KS} / \mathrm{S}$ ANALOG INPUT MODULE

Instrument Identification

PO Number: 337683

Model Number: NI 9205

Serial Number: 12ECB77

\section{$\star C L A S S$ Certificate of Calibration}

3214150

Certificate Page 1 of 1

Accuracy: Mfr Specifications

Certificate Information

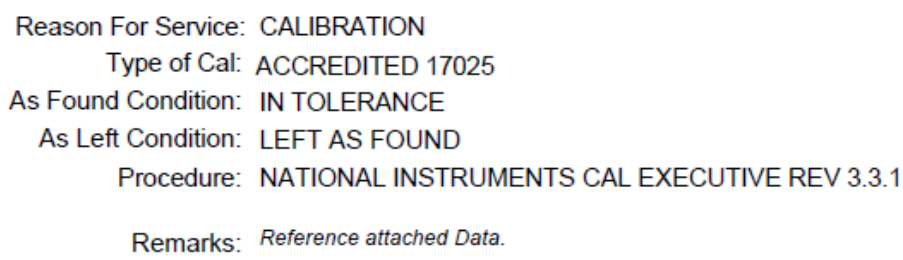

Technician: WAYNE GETCHELL

Cal Date 06May2009

Cal Due Date: 06May2010

Interval: 12 MONTHS

Temperature: $23.0 \mathrm{C}$

Humidity: $47.0 \%$

\footnotetext{
The instrument on this certification has been calibrated against standards traceable to the National Institute of Standards and Technology (NIST) or other recognized national metrology institutes, derived from ratio type measurements, or compared to nationally or internationally recognized consensus standards.

A test uncertainty ratio (T.U.R) of 4:1 [ $K=2$, approx. $95 \%$ Confidence Level] was maintained unless othenvise stated.

Davis Calibration Laboratory is certified to ISO 9001 :2000 by Eagle Registrations (certificate \# 3040). Lab Operations meet the requirements of ANSINCSL Z540-1-1994, ISO 10012:2003, 10CFR50 AppxB, and 10CFR21

ISOIEC 17025-2005 accredited calibrations are per ACLASS certificate \#AC-1187 within the scope for which the lab is accredited.

All results contained within this certification relate only to item(s) calibrated. Any number of factors may cause the calibration item to drift out of calibration before the instrument's calibration interval has expired.

This certificate shall not be reproduced except in full, without written consent of Davis Calibration Laboratory.
}

Approved By: VICTOR PENA

Service Representative

Calibration Standards

\begin{tabular}{|c|c|c|c|c|c|}
\hline NIST Traceable\# & Inst. ID\# & Description & Model & Cal Date & Date Due \\
\hline 3143038 & $15-0271$ & MULTIFUNCTION CALIBRATOR & $5700 \mathrm{~A}$ & 15Apr 2009 & 14Jul2009 \\
\hline
\end{tabular}

Davis Calibration • 2324 Ridgepoint Drive, Suite D • Austin, TX 78754 • Phone: 800-365-0147 • Fax: 512-926-8450

Figure A.9. NI 9205 data acquisition module calibration sheet II 


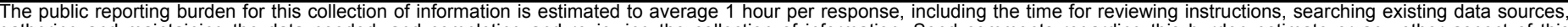

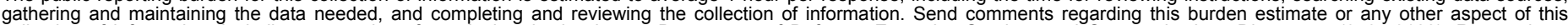

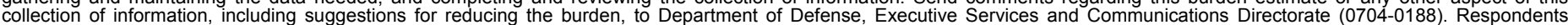

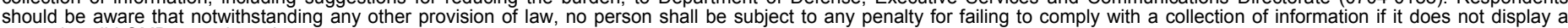

should be aware that notwithstanding

PLEASE DO NOT RETURN YOUR FORM TO THE ABOVE ORGANIZATION.

\begin{tabular}{l|l|l|}
\hline 1. REPORT DATE (DD-MM-YYYY) & 2. REPORT TYPE & 3. DATES COVERED (FrOm - TO)
\end{tabular}

February 2010

Technical Report

4. TITLE AND SUBTITLE

Wind Turbine Safety and Function Test Report for the ARE 442

Wind Turbine

5a. CONTRACT NUMBER

DE-AC36-08-GO28308

5b. GRANT NUMBER

5c. PROGRAM ELEMENT NUMBER

6. AUTHOR(S)

J. van Dam, D. Baker, and D. Jager

5d. PROJECT NUMBER

NREL/TP-500-47030

5e. TASK NUMBER

WE102211

5f. WORK UNIT NUMBER
7. PERFORMING ORGANIZATION NAME(S) AND ADDRESS(ES)

National Renewable Energy Laboratory

1617 Cole Blvd.

Golden, CO 80401-3393

9. SPONSORING/MONITORING AGENCY NAME(S) AND ADDRESS(ES)
8. PERFORMING ORGANIZATION REPORT NUMBER

NREL/TP-500-47030
10. SPONSOR/MONITOR'S ACRONYM(S) NREL

11. SPONSORING/MONITORING AGENCY REPORT NUMBER

12. DISTRIBUTION AVAILABILITY STATEMENT

National Technical Information Service

U.S. Department of Commerce

5285 Port Royal Road

Springfield, VA 22161

13. SUPPLEMENTARY NOTES

14. ABSTRACT (Maximum 200 Words)

This test was conducted as part of the U.S. Department of Energy's (DOE) Independent Testing project. This project was established to help reduce the barriers of wind energy expansion by providing independent testing results for small turbines. In total, four turbines were tested at the National Wind Technology Center (NWTC) as a part of this project. Safety and function testing is one of up to five tests that were performed on the turbines, including power performance, duration, noise, and power quality tests. Test results provide manufacturers with reports that can be used for small wind turbine certification. The test equipment includes an ARE 442 wind turbine mounted on a $100-\mathrm{ft}$ free-standing lattice tower. The system was installed by the NWTC Site Operations group with guidance and assistance from Abundant Renewable Energy.

15. SUBJECT TERMS

ARE 442 wind turbine; safety and function test; independent testing project; small wind turbines

\begin{tabular}{|c|c|c|}
\hline $\begin{array}{l}\text { a. REPORT } \\
\text { Unclassified }\end{array}$ & $\begin{array}{l}\text { b. ABSTRACT } \\
\text { Unclassified }\end{array}$ & $\begin{array}{l}\text { c. THIS PAGE } \\
\text { Unclassified }\end{array}$ \\
\hline
\end{tabular}

\begin{tabular}{|c|c|}
\hline $\begin{array}{l}\text { 7. LIMITATION } \\
\text { OF ABSTRACT }\end{array}$ & $\begin{array}{l}\text { 18. NUMBER } \\
\text { OF PAGES }\end{array}$ \\
\hline UL & \\
\hline
\end{tabular}

19a. NAME OF RESPONSIBLE PERSON

19b. TELEPHONE NUMBER (Include area code) 